\title{
Importance of Perceived Brand Ranking for B2B Customers in Making High Risk Purchasing Decision
}

\author{
Mahesh M Kulkarni ${ }^{1} *$ Dr. Nitin Joshi ${ }^{2}$ \\ ${ }^{1}$ Research Scholar, Pacific University, Udaipur M \\ ${ }^{2}$ Dr. V.N. Bedekar College of Management, Thane. M
}

\begin{abstract}
Brand Building and Brand promotions are undoubtedly means of generating large revenues in today's B2B industrial market. However, due to globalization and access to multiple information data base, the organizations with equal brand equities and brand image exists in the Industrial segments. Therefore, it become extremely difficult for the Buying Center in B2B segment to arrive quickly on the purchasing decision. Therefore, in today's intense marketing era, a deliberate attempt is needed to improve the perceived Brand Ranking in the minds of buying center. Strong brand ranking thus has become a very important factor that influences customer perceptions of a brand. In the success of Brand Management, Brand ranking is gaining significant importance alongwith brand equity from understanding and managing them correctly. Today's marketing professionals need to pay deliberate attention to Brand ranking so as to produce strong attributes that will influence customers when making their choices.This research paper focuses on the importance brand ranking and how it is being perceived by $B 2 B$ customers while making purchasing decision. This is based on the assumption that the other dimensions such as brand promotions, brand equity are at the same level and the customers knowingly and unknowingly makes a comparison based on the rank of the brand.However, this research paper aims to find out if the perceived financial and business risks in the minds of the members of buying center significantly impacts the perceived Brand Ranking. Brand awareness was treated separately from other dimensions because of the difference in scale.A structured questionnaire was constructed to provide answers to our research question. In this study, one hundred questionnaires were distributed, but only eightytwo questionnaires were received out of which seventy six has been realized. The study surveyed four dimensions of perceived risk, value proposition, brand Imageand brand ranking of two top brands in lubricants. Among these dimensions, brand image appears to have the least brand ranking rating by consumers than the other dimensions. However, all these dimensions more or less influence the perceived brand ranking by the customer.
\end{abstract}

\section{Introduction}

Today's Industrial world is rapidly changing due to the globalization and easy access to the global market and there is an intense competition experienced between the various firms. This demands for more innovative and cost effective efforts in marketing management due to which "Brand Management" has become extremely important. Good brand management brings about clear differentiation about the performance and quality of products, improve customer loyalty and preferences and can help to enhance and gain greater market share. Aaker (1991) is of the view that establishing and managing brand should not be taken to be the core operating target for most industries but should also be seen as a source of competitiveness. In other words, value is added to a brand when the brand is able tocompete successfully with other brands and results in improved brand ranking. Addition of value delights customer and here it becomes a preferred choice. This research work is based on this concept and named as "Brand Ranking"Aaker (1991).

Many researcher have been interested in the concept and measurement of brand equity because of the necessity in today's marketplace to develop, maintain and use product branding to acquire a certain level of competitive advantage.This is true especially in the consumer market since the complexities involved are limited. However, in the Industrial market because of the complex nature of product and its subsequent implications on the business, this has led to various points of view on brand management, the factors that affect it, and the perspective from which it should be studiedAilawadi et al., (2003). A strong brand allows customers to have a better perception of the intangible product and services. Also they lessen customer's perceived monetary, safety and social risk in purchasing services which are hard to ascertain before purchase. Strong brands offer a lot of advantages such as reduced competition, larger brand loyalty and increase response to price adjustment by customers, larger profit and brand extensions to a service firm than brands that are not strong.(Aaker 1991) Brands are highly regarded as an important source of capital for most business. The term brand has different meaning attached to it; a brand can be defined as a name, logo, symbol and identity or a trademark. Prasad and Dev. (2000) also states that a brand can be seen to include all tangible and intangible attributes that a business stands for. In the past research carried out by Chaudhuri, A., and Holbrook, M.B. (2001), lots of global and local brands of different products have been used to measure various dimensions of 
brand management however brand ranking in the manufacturing industry such as metal forming industry have never explored. Some research studies carried out similar work in service market and stated that the main brand is the firm's brand while in packaged goods market, the main brand is seen to be the product brand. In today's dynamic industrial market, a powerful brand and associated experience will enhance a customer's attitude and his/her perception towards brand.According to Keller (1993), customer awareness and association influences inferred attributes, perceived quality and finally result to improved brand equity. In addition, the advantage of this dimensionality of customer-based brand loyalty and a systematic evaluation allows marketing managers to study how their marketing programs enhance their brand values and brand ranking in the minds of customers. The best way to build brand ranking is through continuous and deliberate attempt to provide value based services to customer and delight them with performance, quality and service. This will help to create strong and long lasting emotional bonds with customers, and the brand ranking will always remain at the top of the table.

\section{Literature Review}

Extensive Review of the literature resulted into the fact that there are severalmethods proposed to evaluate product technologies. There are also several studies that explored marketing strategies like Branding, Brand Equity and Brand promotion, etc. But, it has been noticed and identified during the literature survey that there was not or a very little emphasis placedon the integration of perceived brand ranking. The researcher is of the opinion that this study which is based on the assessment of Brand ranking in B2B metal forming industries, will help to evaluate its influence on the purchasing decision made by buying center.To better understand the importance of brand equity on customer perceptions of a brand, it is necessary to have an overview of behavior. Belch and Belch (2004) defined consumer behavior as "the process and activities people engage in when searching, selecting , purchasing, using, evaluating and disposing of product and services so as to satisfy their needs and desire". According to Ugala (2001), two types of customer behavior exist, i.e. cognitive and experience-orientedconsumer behavior. Customers with cognitive behavior are logical and rational while experience oriented consumers have more emotional reason to want to purchase a product Chaudhuri, A., and Holbrook, M.B. (2001) characterized customer behavior into four i.e. rational, learned, unconscious and social behavior and they are represented by knowledge, Attitude and Action.

Another key finding of the Myers and Marquis study was the importance of organizational marketing communication, both internal and external. According to their study, informationgenerated, a major portion of the information requiredto develop the innovations. This finding suggests the need for strong interfaces betweenthe functional groups particularly between R\&D and marketing. This clearly indicates that there needs to be a strong integration of the newly developed product technologies and also Branding of these products differently into the market. Approach adopted by various Multi-national Companies is building of strong brand equity is of utmost priority. However, objective of attaining Brand ranking and Brand loyalty is not always an easy task due to high volume requirement of products and services. Price in the form of Value and brand equity is the only possible means by which customers can differentiate one brand from another. Recently, brand promotion has been one of the most important marketing strategy which has led to constant price pressure. As a result, there is some kind of weakening happening w.r.t customers loyalty.

When reading through literatures, we found limited researches regarding customer based-brand ranking in industry and most of them focus on the relationship between brand equity and firm performance using brand awareness and image as moderating effect. Also we noticed that most researches \{Aaker (1991), Keller (1993), Lasser et al (1995), Yoo et al (2000), Yoo and Donthun (2001), Lin and Chang (2003) etc. that surveyed these four dimensions of customer based-brand equity (brand awareness, perceived quality, brand loyalty and brand image) have suggested that they all have influence on consumer. Kotler et al (2005) defined a brand as "a name, term, sign, symbol, design or a combination of these that identifies the makers or seller of the product or services". This definition is based on the use of a brand name, symbols and signs to distinguish a product from its competitor. Prasad and dev (2000) noted that a brand can also be said to include all tangible and intangible attributes that the business stands for. According to Keller (2003 p.3), the American market association (AMA) defines a brand as a"name, term, sign, symbol or design or a combination of them, intended to identify the goods and services of one seller or group of sellers and to differentiate them from those of competitor". Jones and Slater (2003) sum up these added values as those that develop from experiences of the brand; those that arise as a result of usage of the brand, which could be as a result of consumers association with the brand; those that arise from an assumption that the brand is powerful; and those that arise from the appearance of the brand i.e. packaging the product.Wind Yoram and Webster Fedrick E. Jr (1972) in the research tile "On the Study of Industrial Buying Behavior: Current Practices and Future Trends" defined the organizational buying research as an integral part of market research. In the research paper published in the Industrial Marketing Management the emphasis was put on some basics of research and how it can be applied in studying the Industrial Buying Behavior. It has been clearly stated in this paper that buying behavior of organizations are as important to the 
industrial marketer as they are to vendors of consumer goods, though in the industrial case it is considerably more complicated than studies of consumerbehavior.

Webster and Wind (1972) in their earlier research also studied central characteristics of organization buying which effects a number of critical research decisions such as;

(1) Individual and the number of participants in the buying center $\mathrm{v} / \mathrm{s}$ the organizations itself and the members influencing the decisions.

(2) Appropriate Market Segment Analysis v/s Industry Organization

(3) Dependent variable specifications - Some of the variables may be common such as Purchase, attitudes, etc. but in organizational buying it may differ in Source Loyalty than Brand Loyalty (Wind 1972)

(4) Independent variable specifications such as Individual traits, interpersonal characteristics organizational factors and environmental Characteristics as explained in Wind (1972).

Schmitt (1999) said that a brand should not just be an identifier, he went further to say that a good image and name is insufficient; delivered experience is also important. The brand has to be viewed as an identifier where the logo, slogan, names forms a particular image and awareness for the consumer. The brand has to be viewed as an experience provider where the logo, slogan, names, event and contacts by consumer provides consumers affective, sensory, lifestyle and create relation with the brand.

Conclusively, a brand can be said to be a symbol of all facts associated with a product and service and Brand ranking is said to be the positive/negative perception about the brand based on the satisfaction level. A brand commonly includes a $\log$, a name and any other visible elements such as symbols and images. It also consists of other sets of expectation related to a product or service which normally arise in people's mind.

\section{Product Technology And Branding Grid}

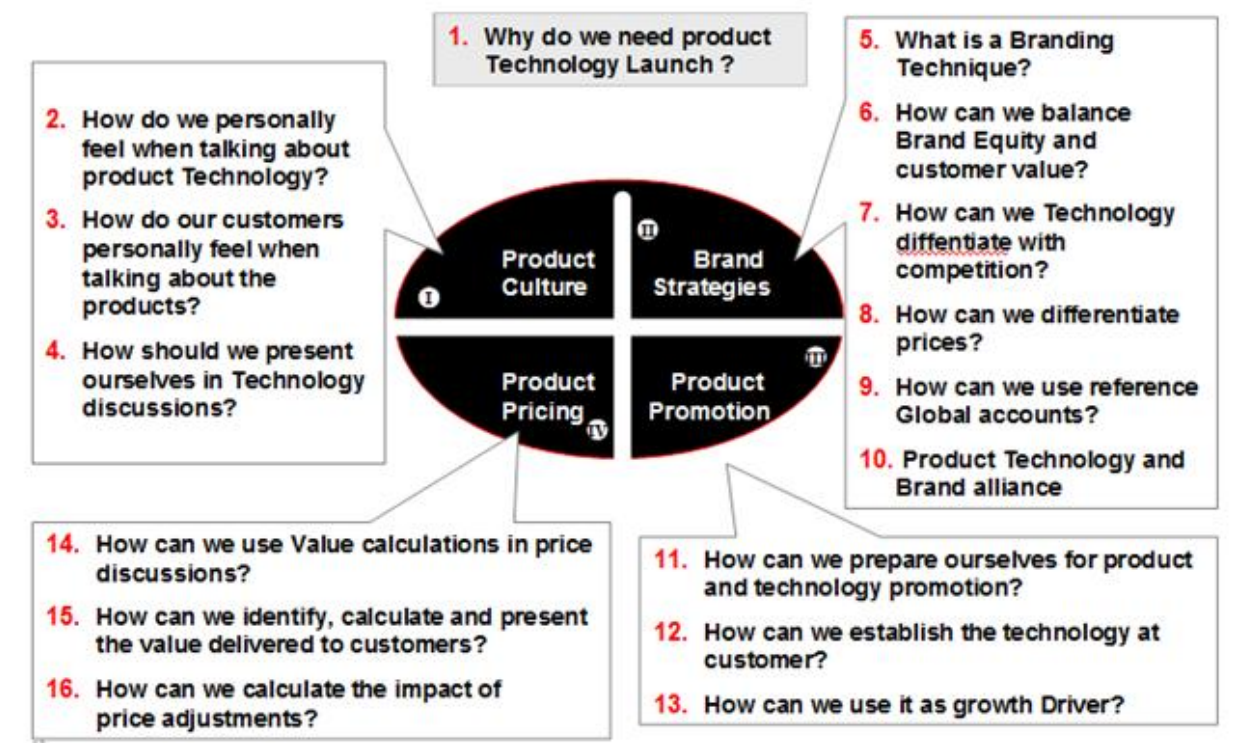

\section{Methodology}

The general purpose of the research is to examine the possible relationship between effects of brand ranking on the purchasing decision in $\mathrm{B} 2 \mathrm{~B}$ metal forming industries. The author hypothesize that the organizations with intense brand management and promotional campaigns which exhibit a high degree of strategic focus may not be inclined towards the improving the brand ranking as perceived by their customers.Moreover, the extreme of a focused strategy would be represented by a firm that without fail takes small steps of incremental improvement for enhancement of brand ranking to a specific set of customer. The authors of this article tried to present the findings of a survey designed to obtain insights regarding the extent to which brand ranking can influence the decision making and its impact on the Brand and image of the organization. In specific, the objective of the study is (1) determine the impact of product technology on brand of the organization (2) identifying the primary appeals employed in the business success and (3) determination of the roles of marketing in the branding of the organization with the help.

A highly structured closed end questionnaire which includes the use of statements and Likert like scaling techniques was employed in surveying the two group of respondents. One group which was comprising manufacturing and quality professionals and the other one is Marketing and senior management personnel who is instrumental is Brand promotion activities. The instrument has been circulated to one hundred (100) personnel's in ten (10) B2B metal forming industries especially in Maharashtra state of India. Responses 
received from eighty two (82) respondants in hard copies as well on line surveys through e-mail out of which 6 were incomplete. Seventy six (76) responses are realized for further analysis. It should also be noted that the authors are cognizant of the limitations presented by the balance 6 respondents as they were of the opinion that the organizations has given a very little or no importance to brand promotions and their response may not be genuine and authentic.

Data Analysis

The 76 respondents are presented below;

Table 1 -Demographic Data

\begin{tabular}{|l|l|l|l|}
\hline S. No. & Item Description & Frequency & Percentage \\
\hline I & Gender & & \\
\hline 1 & Male & 68 & $89.47 \%$ \\
\hline 2 & Female & 8 & $10.53 \%$ \\
\hline 3 & Others & 0 & $0.00 \%$ \\
\hline & Total & $\mathbf{7 6}$ & $\mathbf{1 0 0 . 0 0 \%}$ \\
\hline II & Age & & \\
\hline 1 & Between 25 and 30 & 8 & $10.53 \%$ \\
\hline 2 & Between 30 and 35 & 10 & $13.16 \%$ \\
\hline 3 & Between 35 and 40 & 24 & $31.58 \%$ \\
\hline 4 & Between 40 and 45 & 26 & $34.21 \%$ \\
\hline 5 & Above 45 Years & 8 & $10.53 \%$ \\
\hline & & $\mathbf{7 6}$ & $\mathbf{1 0 0 . 0 0 \%}$ \\
\hline III & Functions/Departments & & \\
\hline 1 & Senior Management & 12 & $15.79 \%$ \\
\hline 2 & Manufacturing & 20 & $26.32 \%$ \\
\hline 4 & Quality & 16 & $21.05 \%$ \\
\hline 5 & Marketing & 28 & $36.84 \%$ \\
\hline & & $\mathbf{7 6}$ & $100.00 \%$ \\
\hline
\end{tabular}

The respondents have been asked different questions through questionnaire but most of the questions are classified under four categories. These are;

1. Perceived Brand Attributes

2. Perceived Risk of Adoption

3. Value Proposition offered by suppliers

4. Brand Ranking based on the proposition

The questionnaire has been analyzed on Likert scales on a 5 points scale starting with Strongly Disagree (1) and strongly Agree (5). We discuss the findings based on the above 4 points and its outcome for two suppliers with Brand I and Brand II.

Table 2: Mean difference of perceived brand attributes between Brand I and Brand II.

\begin{tabular}{|l|l|l|l|l|}
\hline Perceived BrandImage Attributes & $\begin{array}{l}\text { Brand-I Mean } \\
\text { value }\end{array}$ & Std & $\begin{array}{l}\text { Brand- } \\
\text { IIMean value }\end{array}$ & Std \\
\hline The Brand promotions is good. & 4.22 & 0.66 & 4.68 & 0.48 \\
\hline $\begin{array}{l}\text { Service offerings and Brand are complementary to } \\
\text { each other. }\end{array}$ & 4.78 & 0.47 & 4.58 & 0.67 \\
\hline Product availability is easy & 4.94 & 0.34 & 4.34 & 0.58 \\
\hline $\begin{array}{l}\text { Brand Equity and Value provided by the company is } \\
\text { significant. }\end{array}$ & 4.31 & 0.74 & 4.28 & 0.59 \\
\hline $\begin{array}{l}\text { Sales force and Service people are knowledgeable and } \\
\text { co-operative. }\end{array}$ & 4.41 & 0.59 & 4.13 & 0.49 \\
\hline Over all Mean value & $\mathbf{4 . 5 3}$ & & $\mathbf{4 . 4 0}$ & \\
\hline
\end{tabular}

Table 3: Mean difference of perceived Risk between Brand I and Brand II

\begin{tabular}{|l|l|l|l|l|}
\hline Perceived RiskAttributes & $\begin{array}{l}\text { Brand I Mean } \\
\text { value }\end{array}$ & Std & $\begin{array}{l}\text { Brand II Mean } \\
\text { value }\end{array}$ & Std \\
\hline $\begin{array}{l}\text { Risk Perceived for introducing a new process lubricant } \\
\text { is higher. }\end{array}$ & 4.45 & 0.72 & 3.95 & 0.49 \\
\hline $\begin{array}{l}\text { Deciding authority is ready for calculated risk for } \\
\text { introducing new products. }\end{array}$ & 3.99 & 0.33 & 3.83 & 0.52 \\
\hline $\begin{array}{l}\text { When there is high risk involved and the choice has } \\
\text { important consequences }\end{array}$ & 4.62 & 0.79 & 4.22 & 0.64 \\
\hline $\begin{array}{l}\text { Case histories help to reduce risk and accelerate the } \\
\text { decision process. }\end{array}$ & 4.34 & 0.66 & 4.12 & 0.48 \\
\hline $\begin{array}{l}\text { Risk Attitudes and experience affect the decision making } \\
\text { in the buying process. }\end{array}$ & 4.14 & 0.13 & 4.20 & 0.25 \\
\hline Over all Mean value & $\mathbf{4 . 3 0}$ & & $\mathbf{4 . 0 6}$ & \\
\hline
\end{tabular}


Table 4: Mean difference of perceived Value between Brand I and Brand II

\begin{tabular}{|l|l|l|l|l|}
\hline Value Proposition Attributes & $\begin{array}{l}\text { Brand I Mean } \\
\text { value }\end{array}$ & Std & $\begin{array}{l}\text { Brand II Mean } \\
\text { value }\end{array}$ & Std \\
\hline The proposal submitted is value driven. & 4.15 & 0.72 & 3.65 & 0.49 \\
\hline Experienced Technical staff provides useful information. & 3.89 & 0.33 & 3.63 & 0.52 \\
\hline $\begin{array}{l}\text { Provides case histories from similar industry and product } \\
\text { limes. }\end{array}$ & 4.42 & 0.79 & 3.92 & 0.64 \\
\hline $\begin{array}{l}\text { Documentation on Value proposition is clear and } \\
\text { logical. }\end{array}$ & 4.14 & 0.66 & 3.69 & 0.48 \\
\hline $\begin{array}{l}\text { Brand image plays a vital roles and complements value } \\
\text { proposals. }\end{array}$ & 4.04 & 0.13 & 4.10 & 0.25 \\
\hline Over all Mean value & $\mathbf{4 . 1 3}$ & & $\mathbf{3 . 7 8}$ & \\
\hline
\end{tabular}

Table 5: Mean difference of brand ranking between Brand I and Brand II

\begin{tabular}{|l|l|l|l|l|}
\hline Brand Ranking Attributes & $\begin{array}{l}\text { Brand IMean } \\
\text { value }\end{array}$ & Std & $\begin{array}{l}\text { Brand- } \\
\text { IIMean value }\end{array}$ & Std \\
\hline Its brand is familiar to me. & 4.89 & 0.24 & 4.47 & 0.50 \\
\hline The price is reasonable. & 4.26 & 0.65 & 4.94 & 0.81 \\
\hline It has reliable references & 4.88 & 0.93 & 4.41 & 0.58 \\
\hline The information provided is authentic and trustworthy. & 4.41 & 0.64 & 4.53 & 0.50 \\
\hline It has a long history. & 4.78 & 0.45 & 3.78 & 0.68 \\
\hline Over Mean Value & $\mathbf{4 . 6 4}$ & & $\mathbf{4 . 4 2}$ & \\
\hline
\end{tabular}

\section{Discussions}

As earlier predicted,all the dimension of customer based brand ranking will have influence on consumer's perception of brand. From our finding, among these three dimensions of consumer-based brand equity i.e. perceived risk, perceived value and perceived brand image, which has to do with customer's choice towards brand, appears to have the brand ranking rating.Perceived value and value proposition attributes got the lowest rating in the three dimensions for both brands. Although the three dimensions are important in brand ranking construct. The fact that brand ranking may had the least influence on consumer's perception of brand is a logical issue because even when the consumers seems to be satisfied they appear not to be too loyal. One possible reason could be the price of the product and the other one is what perceived value of customer is?

\section{Conclusion}

With Brand image, we found out that there were some mean differences between Brand I and Brand II on all the five attributes of brand image except "Brand Equity and value provided ...". Respondents rated Brand I than Brand II on the following attributes "its brand is familiar to me, Product is easily available and sales force is knowledgeable and cooperative. Brand II tends to achieve high perceived attributes such as 'Service offerings and Brand are complementary to each other. In the perceived risk attribute Brand I is having inclination towards the dimensions such as higher Risk Perceived for introducing a new process lubricant, the final choice has important consequences and Case histories help to reduce risk and accelerate the decision process. However, Brand II also has some important dimensions which respondent perceive it as Risk Attitudes and experience affect the decision making in the buying process and the value proposals complement to improve brand ranking. Finally, the brand ranking has been based on five dimensions out of which Brand I has scored significantly over Brand II. The dimensions which are considered of vital respondents are; Familiarity of the Brand, reliable references for the similar product lines and long historical presence in the similar product lines. Although Brand II has been perceived as price competitive and authentic information, Brand I ranking is at the top of the table in the minds of the respondents and have edge over Brand II in winning the business.

\section{Acknowledgement}

The authors would like to thanks Dr. Hemant Kothari - Dean Pacific University and Mr. Ramesh Agarwal - Pacific University (Mumbai Region) for their valuable guidance in statistical workshop in Mumbai. The authors would also like to thank Mr, Suresh Gavade, Nilesh Kulkarni and Mahadev for their 'timely help in collecting the data from respondents. Last but not the least, all those friends who are directly or indirectly involved in carrying out this work.

\section{References}

[1]. Aaker, D. A., (1991). "Managing brand equity capitalizing on the value of a brand name". New York: Free Press. Aaker, D. A., (1996). "Building strong brand". New York: Free Press.

[2]. Ailawadi, K.L., Lehman, D.R., \&Neslin, S.A. (2003). Revenue premium as an outcome measure of brand equity. Journal of Marketing, 67, 1-17.

[3]. Belch, G. E., \& Belch, M. A. (2004) "Advertising and Promotion: An Integrated Marketing Communications Perspective”, (6th: New York: NY: McGraw-Hill. 
[4]. Blackwell, R.D., Miniard, P.W. and Engel, J.F. (2001) Consumer Behavior, 9th edn, Orlando, FL: Harcourt

[5]. Chaudhuri, A., and Holbrook, M.B. (2001). "The chain of effect from brand trust and brand effect to brand performance; the role of brand loyalty". Journal of marketing, 65 (2), 81-93.

[6]. Ghauri, P. and Gronhaug, K. (2005) "Research Methods in Business Studies: A practical Guide". (3rd edn.), Pearson Education Limited

[7]. Hanson, R. (2002). “Turkey HRI food service sector report”. USDA Foreign Agricultural Service Gain Report \#TU2012. Available from http://fas.usda.gov

[8]. Jones, J. and Slater, J.S. (2003) what's in a Name? - Advertising and the Concept of Brands, 2nd edition, New York.

[9]. Keller K.L (1993) "Conceptualizing, Measuring and Managing Customers-Based Brand Equity” Journal of Marketing Management $57,1-12$

[10]. Kotler p. and Armstrong, G. (2004) "principle of marketing” (10th edition) New Jersey: prentice hall

[11]. Lassar, Walfried, Banwari Mittal \&Arun Sharma. (1995) "Measuring Customer- Based Brand Equity" Journal of Consumer Marketing, Vol. 12, No. 4.

[12]. Lin, M.Y., and Chang, L.H (2003) "Determinant of habitual behavior for national and leading brands in chain" journal of product and brand management (94-107)

[13]. Prasad, k., and Dev, C.S (2000) Managing hotel brand equity: a customer-centric framework for assessing performance.coenell hotel and restaurant administration quartely.41 (3), 22-31.Schmitt, B.H (1999) experiential marketing. New York

[14]. Taylor, S.A., Baker \& T.L, 'An Assessment of the Relationship Between Service Quality and Customer satisfaction in the formation of Consumers' Purchase Intentions,' Journal of Retailing, 1994, Vol. 70, pp. 163-178.

[15]. Yoo.B, Donthum.N. (2001) "Developing and Validating a Multidimensional Customers-Based Equity Scale" Journal of Business Research, 52(1) 1-14.Publications, 1994.

[16]. Z Zinkmund, W (2000) "Business Research Methods" (6th edition) Orlando: The DrydenPress 